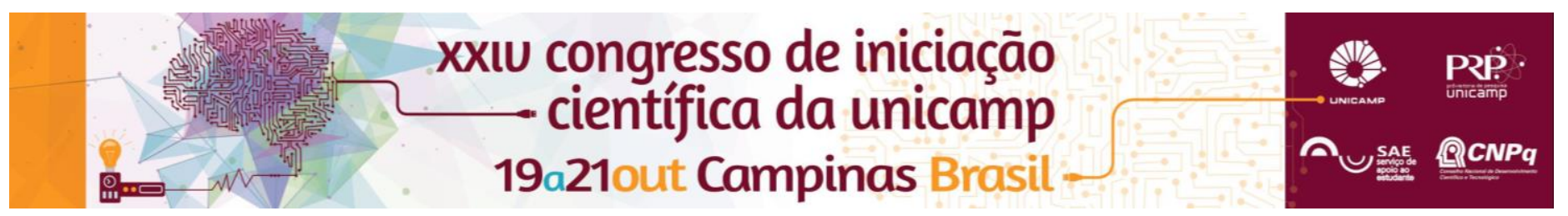

\title{
Análise Estatística do Perfil de Aves Poedeiras da Raça White Leghorn.
}

\author{
Giovanna S. Silva*, Rafael P. Maia.
}

\section{Resumo}

Esse trabalho dará ênfase no estudo das linhas de aves de postura, mais especificamente, nas linhas da raça White Leghorn, buscando, através dos dados fornecidos pela Embrapa Suínos e Aves, traçar o perfil das aves ao longo das gerações estudadas. De modo geral, as aves de todas as linhas de postura sofreram seleção em relação as seguintes características: idade de maturidade sexual, fertilidade, eclodibilidade, menor peso da ave ao início e ao final da postura entre outras características. O objetivo é identificar alterações no perfil das aves ao longo das gerações e avaliar os efeitos do processo de melhoramento genético, principalmente em relação a produção de ovos.

\section{Palavras-chave:}

Estatística-descritiva; aves de postura.; melhoramento genético

\section{Introdução}

O Brasil sempre foi um país de importância no cenário mundial quando se trata de pesquisa agropecuária. Por isso, a Embrapa Suínos e Aves desenvolveu um programa de melhoramento genético completo que teve início em 1982 com a formação de populações de aves para corte e de postura. O principal objetivo foi o desenvolvimento de linhagens comerciais visando minimizar a dependência da importação de material genético básico (Ledur et. al, 2011).

Os dados foram cedidos pela Embrapa Suínos e Aves e fazem parte de um programa de melhoramento genético das aves de postura da raça White Leghorn. Essas aves estão sob constante processo de seleção e temos como objetivo apresentar análise estatística detalhada identificando alterações no perfil dessas aves ao longo de 9 gerações. A principal característica avaliada é a produção semanal de ovos. Nosso interesse é de apresentar parâmetros para avaliar a eficiência do programa de melhoramento genético desenvolvido pela Embrapa.

Além disso, o projeto visa o aprendizado continuado, por parte do aluno de Iniciação Científica, de conceito e métodos de estatística descritiva e do software estatístico $R$ (R Core Team, 2015) para a realização das análises do conjunto de dados em estudo.

\section{Resultados}

Nesse trabalho foram avaliadas 9 gerações do programa de melhoramento da Embrapa, cada geracão com duração de 70 semanas. Nosso estudo avalia os dados das aves da 9 até a geração 17. O peso com 16 semanas das aves varia 1240 gramas (geração 16) e 1348 gramas (geração 12). De modo geral, não observamos grade variação na distribuição do peso das aves as 16 semanas ao longo das gerações.

O início de produção de ovos varia entre as aves ao longo das gerações, no entanto, a grande maioria das aves já havia atingido a idade de maturação sexual na semana 25 A Figura 1 apresenta o gráfico da produção média de ovos por semana, da semana 25 até a semana 56, e por geração. A primeira característica que observamos é a diminuição na produção a medida que as aves envelhecem. Por exemplo, na geração, a produção média varia de 4,6 ovos na semana 25 a 3,9 ovos 53. Notamos ainda variação entre as gerações, a nona geração é que apresenta menor produção média. As gerações que mais produziram são as 15,16 e 17 , que são as três gerações mais recentes. As gerações 15 e 16 são as que mais sofreram queda na produção durante as semanas. Na semana 25 elas possuem, respectivamente, uma média de aproximadamente 4,7 e nas últimas semanas a média cai para aproximadamente 4,2, respectivamente. Já geração 17 se mantêm sem muita variação na média permanecendo no intervalo de 4,7 até 4,4 .

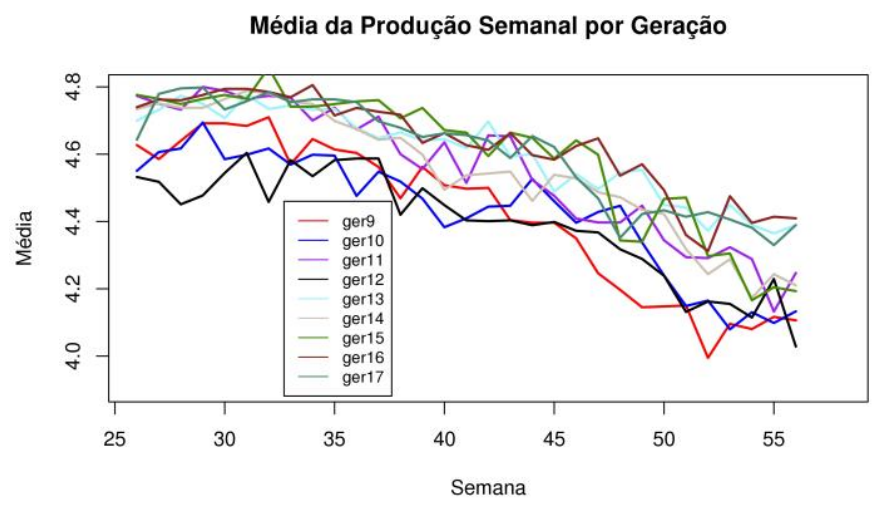

Figura 1. Produção média de ovos por semana e por geração.

\section{Conclusões}

De acordo com as aos dados analizados, observamos que há evidências de um aumento gradual em relação a produção semanal de ovos ao longo das gerações estudadas. A produção semanal média das gerações mais jovens é ligeiramente maior que das gerações mais antigas.

\section{Agradecimentos}

Agradecemos a Embrapa Suíno e Aves, Concórdia / SC, por fornecer os dados para o estudo.

\footnotetext{
${ }^{1}$ LEDUR, M. C.; DE FIGUEIREDO, E. A. P.; SCHMIDT, G. S.; DE AVILA, V.S.;PEIXOTO, J.O. O melhoramento genético de aves no Brasil e as contribuições da Embrapa Suíno e Aves. Em: Sonho, Desafio e Tecnologias. Em: Sonho, Desafio e Tecnologias; 35 anos de Contribuições da Embrapa Suínos e Aves, editores: SOUZA, J.C.P.V.B.;Talamini, D.J.D; Schumann, G.N;Schimidt. G.S., Embrapa, 2011. Capítulo 11, p. 293 - 316.
} 